\title{
Dietary yerba mate (Ilex paraguariensis) influences lipid profile of broiler meat
}

\author{
Erva mate na dieta influencia o perfil lipídico da carne de frangos de corte
}

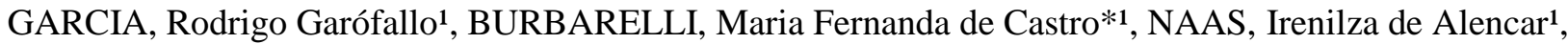 \\ SGAVIOLI, Sarah², CARDOSO, Claudia Andrea Lima³, BELINTANI, Rafael¹, CALDARA, Fabiana \\ Ribeiro $^{1}$
}

\author{
${ }^{1}$ Universidade Federal da Grande Dourados, Dourados, MS, Brasil \\ ${ }^{2}$ Universidade Brasil, Descalvado, SP, Brasil \\ ${ }^{3}$ Universidade Estadual de Mato Grosso do Sul, Dourados, MS, Brasil \\ *Correspondence Author
}

\section{SUMMARY}

Yerba mate (Ilex paraguariensis)has in its composition organic compounds wich can modify chemical composition of broiler meat. This study aimed to evaluate the influence of yerba mate in chemical composition and lipid profile of broiler breast and thigh meat. The trial was conducted using 500 broiler chicks distributed in a completely randomized design with four treatments $(0.1 ; 0.2 ; 0.4$, and $0.6 \%)$ and five replicates with 25 chicks each. The chicken were raised form 1 to 42 days old and slaughtered for analysis of breast and thigh meat. The addition of mate did not affect the chemical composition and the lipid profile of the chicken breast, however, the composition of the meat of thigh meat was affected. It was observed effect of the addition of the yerba mate to saturated, unsaturated, monounsaturated and polyunsaturated fatty acids in the chicken meat. Stands out the reduction in saturated fatty acid concentrations and the increase in the concentrations of polyunsaturated fatty acids, especially Linolenic and Eicosapentaenoic, thus demonstrating the potential of mate grass in altering the lipid profile of poultry meat.

Keywords:centesimal composition, fatty acid profile, meat, poultry, yerba mate

\section{RESUMO}

A erva mate (Ilex paraguariensis) possui em compostos orgânicos com propriedades de modificar a composição química de carne de frangos de corte, desta maneira este estudo avaliou a influência da erva mate sobre a composição química e o perfil lipídico de carne de peito, coxas e sobrecoxas de frangos de corte. Foram utilizados 500 pintainhos de corte distribuídos em um delineamento inteiramente casualizado com inclusões de erva mate nas dietas $(0.1 ; 0.2 ; 0.4$, e $0.6 \%)$ com quatro repetições de 25 aves em cada tratamento, criados de 1 a 42 dias de idade para posterior abate e análises da composição de cortes cárneos. $A$ adição de erva mate não afetou a composição química e o perfil lipídico dos peitos de frangos, porém a composição da carne de sobrecoxas foi afetada. Foi observado efeito da adição da erva mate em ácidos graxos saturados, insaturados, monoinsaturados e poli-insaturados na carne de sobrecoxas de frango, destacando-se a redução nas concentrações de ácidos graxos saturados e o aumento das concentrações dos ácidos poliinsaturados, em especial Linolênicoe Eicosapentaenoico, demonstrando assim o potencial da erva mate em alterar o perfil lipídico da carne de aves.

Palavras-chave: avicultura, carne de frango, composição centesimal, erva mate, perfil lipídico 


\section{INTRODUCTION}

Ilex paraguariensis (yerba mate) is cultivated in Brazil, Argentina, Uruguay, and Paraguay, and the dried leaves used to prepare an infusion with a bitter taste stimulant (Racanicci et al. 2008). Mate has polyphenols contents, flavonoids, saponins, and xanthines which have anti-inflammatory characteristics (Lanzetti et al. 2008), antimicrobials (Filip et al. 2001), and antioxidants features (Bracesco et al. 2010).

Those characteristics can be cited as beneficial to performance and meat quality of broilers. Also, antioxidant potential of mate leads to meat preservation and nutritional quality improvement (Racanicci et al. 2008).

Meat quality is affected by fatty acids composition; on the other hand, dietary fat can influence positively and negatively human health. Recommended diets are compound of low fat content or a high proportion of unsaturated fatty acids. In addition, dietary guidelines for long periods have recommended prevent high intake of saturated fat in order to avoid cardiovascular diseases (Krauss et al. 2000).

Monounsaturated fatty acids (MUFA), specifically oleic acid, have positive influences on cholesterol metabolism, lowering LDL (Wood \& Enser, 2017). Is also known the beneficial potential of polyunsaturated fatty acids (PUFAs), especially the $n-3$ fatty acids, on human health. These fatty acids can be obtained in diets or produced by organisms. The amounts produced by organisms many times are not sufficient to balance relations between unsaturated and saturated fatty acids due to insufficient ingestion of energy, proteins, zinc, magnesium, cooper, B3, B6 and C vitamins (Brenner, 1981; Liu \& Ma, 2014).

The composition of muscle is affected by the composition of diets, especially fatty acid composition (Wood et al. 2013). Also, fatty acid composition also can be influenced by diets containing grass(Moleeet al. 2012) or plant extracts(Ahmed et al.2015). Accordingly, Yerba mate is also known by its potential of influences lipid metabolism mainly in cholesterol, some studies demonstrated the potential of mate in reduce LDL levels and improving prevention of aortic diseases (Mosimann et al. 2006; Lee, 2007).

Regarding the possibility of mate influences muscle fatty acid profile, the present study aimed to investigate the influence of dietary addition of Ilex paraguariensis in centesimal composition and fatty acid profile of meat of broilers slaughtered at $42 \mathrm{~d}$ old.

\section{MATERIAL AND METHODS}

This study was subject to ethical review and approved by the Animal Ethics Committee (CEUA) of the Universidade Federal da Grande Dourados- UFGD, under the protocol number 007/2012. The experiment was conducted in the Poultry Section of the UFGD, Dourados, MS, Brazil, located at latitude $22^{\circ} 13^{\prime} 18^{\prime \prime} \mathrm{S}$, and longitude $54^{\circ} 48^{\prime} 23^{\prime \prime}$ W. A total of 500 day-old male Cobb $^{\circledR} 500$ broiler chicks were divided into 20 pens with 25 birds each using a flock density of 12 birds $\mathrm{m}^{-2}$. The experimental design was completelyrandomized with four treatments related to the levels of addition of yerba mate in broiler diet $(0.1 \% ; 0.2 \% ; 0.4 \%$, and $0.6 \%)$. The poultry house had controlled environment with exhaust fans and pad cooling. During brooding, the heating was done using infrared lamp equally distributed throughout the house. Ambient temperature and relative humidity were maintained accordingly to the lineage manual (CobbVantress, 2009). Broilers were slaughtered at $42 \mathrm{~d}$ old.

The experimental diets were commercial diets formulated with corn and soybean bran according to Rostagno et al. (2011), added the amount of mate according to each treatment, and provided ad libitum.

Dried leaves of Ilex
paraguariensis(BarãoComércio e Indústria de Erva Mate Ltda, Erechim, Brazil) were groundedand put through a fine sieve and shivered continuously to become powder. The composition of the powder was $100 \%$ mate with $8 \%$ humidity, $20 \%$ crude fiber, and $7 \%$ mineral matter. 
At the end of the experimental period $(42 \mathrm{~d}$ old), 32 birds per treatment were selected with similar body weight $( \pm 10 \%$ of the mean weight of the lot) for slaughtering. The birds were stunned, also bleeding and plucking were realized. Evisceration and cuts were performed and the breast (pectoralis major) and thigh (sartorius) were separated for analysis.

Breast and thigh were used for evaluating the centesimal composition and fatty acid profile. For these analyses were used 32 samples of breast and thigh of each treatment, in which were evaluated matter index (DM, \%), mineral matter (MM, \%) and ethereal extract (EE, \%), and crude protein (CP, \%) according to AOAC, 2016. Also was evaluated the fatty acid profile using approximately $10 \mathrm{~g}$ of meat from each cut. The fatty acids were extracted using chloroform-methanol (Bligh \& Dyer, 1959) and the neutral and polar intramuscular from the samples were extracted using a solvent with dichloromethane and dichloromethanemethanol (90:10, $\left.\mathrm{vol} \mathrm{vol}^{-1}\right)$ respectively, in a glass column containing anhydrous sodium sulfate, and dicalcium phosphate (Marmer\& Maxwell, 1981).

Fatty acid analysis was performed by gas chromatography (Hewlett Packard 5890, Houston, USA) using a capillary column with the dimensions of $(30 \mathrm{~m} \times 0.32 \mathrm{~mm} \times$ $0.25 \mu \mathrm{m})$ of glycol polyethylene reticulate.

The analyses were performed with a temperature program of 170 to $245^{\circ} \mathrm{C}$ at a rate of $1^{\circ} \mathrm{C} \mathrm{min}-1$. The injector and the FID (flame ionization detector) were maintained at $250{ }^{\circ} \mathrm{C}$. The drag was performed with
ISSN 15199940

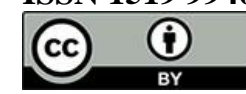

helium gas at a flow rate of $3 \mathrm{~mL} \mathrm{~min}^{-1}$. Pentadecanoic fatty acid was used as the standard of known composition, and calculations were made by integration with a computer connected to the detector. The melting point of the fat was determined by the capillary tube method, according to AOAC (1990).

The fatty acid (\%) examined were from three group, as follows: (1) the saturated fatty acids (Myristic, C14:0; Pentadecanoic, C15:0; Palmitic, C16:0; Margaric acid, C17:0; Stearic acid, C18:0; Nonadecylic, C19:0; Arachidic, C20:0; and Behenic, C22:0), (2) the mono-unsaturated fatty acids (Myristoleic, C14: 1n5; Palmitoleic, C16:1; Oleic, C18:1n9C; Cetoleic, C20:1n11; and Ecozonoic, C20:1n9); and (3) the polyunsaturated fatty acids (Linoleic, C18:2n6c; Elaidic, C18:1n9t; Conjugated Linoleic, C18:2c9t11(CLA); $\alpha$-linolenic, C18:3n3; Arachidonic, C20:4n6; and Eicosapentaenoic, C20:5n3). The data obtained were subjected to ANOVA using the GLM-Minitab 17 statistical software package (Minitab, 2010). Pair wise contrasts were used to show differences between the treatments. The optimal addition of mate was estimated based on a polynomial regression model (linear and quadratic) adopting a probability of $95 \%$.

\section{RESULTS}

There was no significant effect of different levels of mate in poultry diets in centesimal composition of broilers breast meat(Table 1).

Table 1.Centesimal composition of broiler breast and thigh meat with different dietary level of Ilex paraguariensis(yerba mate).

\begin{tabular}{|c|c|c|c|c|}
\hline \multicolumn{5}{|c|}{ Breastmeat } \\
\hline Yerba mate (\%) & $\overline{D M}$ & MM & $\mathrm{EE}$ & $\mathrm{CP}$ \\
\hline 0.1 & 28.34 & 1.24 & 1.75 & 22.53 \\
\hline 0.2 & 28.64 & 1.13 & 1.26 & 22.77 \\
\hline 0.4 & 27.60 & 1.18 & 1.26 & 22.46 \\
\hline 0.6 & 27.34 & 1.24 & 1.26 & 22.40 \\
\hline $\mathrm{p}$ & 0.198 & 0.596 & 0.336 & 0.962 \\
\hline \multicolumn{5}{|c|}{ Thighmeat } \\
\hline & MS & MM & $\mathrm{EE}$ & PB \\
\hline
\end{tabular}


Rev. Bras. Saúde Prod. Anim., Salvador, v.20, 01 - 14, e1022019, 2019 http://dx.doi.org/10.1590/S1519-9940201022019

$\begin{array}{ccccc}0.1 & 29.24 & 1.14 & 8.78 & 20.55 \\ 0.2 & 27.83 & 1.02 & 4.76 & 19.22 \\ 0.4 & 27.76 & 1.03 & 4.63 & 18.93 \\ 0.6 & 28.63 & 1.02 & 6.21 & 18.08 \\ \mathrm{p} & 0.098 & 0.789 & 0.039 & 0.258\end{array}$

Significant at $95 \%(\mathrm{p}<0.05) . \mathrm{DM}=$ dry matter; $\mathrm{MM}=$ mineral matter; $\mathrm{EE}=$ ethereal extract; $\mathrm{CP}=$ crude protein.

Thig meat composition was not affected by the inclusion of mate also, except for EE, which presented a quadratic effect. The

estimated level of $0.35 \%$ was the lowest point for EE (Figure 1).

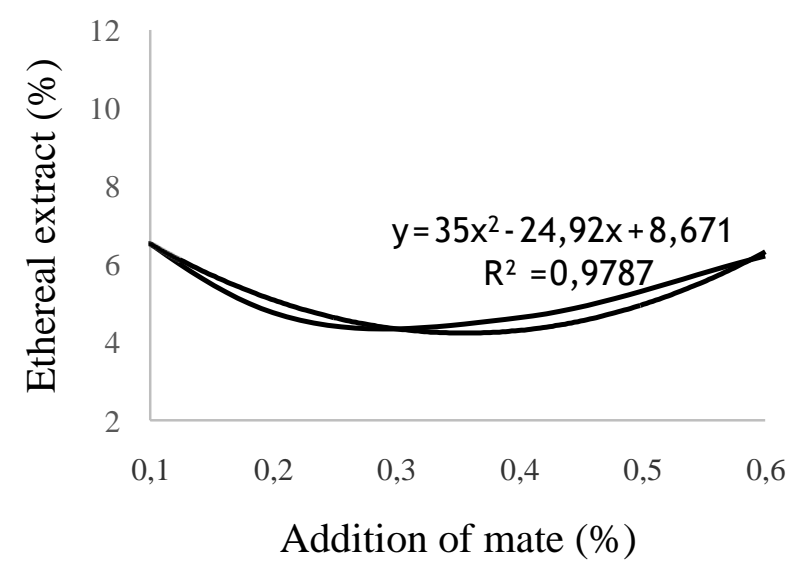

Figure 1. Effects of dietary Ilex paraguariensis (yerba mate) on ethereal extract of thigh meat of broilers

Evaluating saturated fatty acid profile, broilers breast meat was not affected by mate. However,thigh meat presented effects on myristic, palmitic and arachidic(Table 2). 
Table 2. Saturated fatty acids (\%) in the broiler breast and thigh meat with different dietary level of Ilex paraguariensis (yerba mate).

\begin{tabular}{|c|c|c|c|c|c|c|c|c|c|c|c|}
\hline \multirow{3}{*}{ FattyAcid } & & \multicolumn{4}{|c|}{ Breastmeat } & \multicolumn{6}{|c|}{ Thighmeat } \\
\hline & & \multicolumn{4}{|c|}{ Yerba mate (\%) } & \multicolumn{6}{|c|}{ Yerba mate (\%) } \\
\hline & & 0.1 & 0.2 & 0.4 & 0.6 & $\mathrm{p}$ & 0.1 & 0.2 & 0.4 & 0.6 & $\mathrm{p}$ \\
\hline Myristic & C14:0 & 0.496 & 0.474 & 0.522 & 0.496 & NS & 0.832 & 0.676 & 0.684 & 0.626 & $<.0001$ \\
\hline Pentadecanoic & C15:0 & 0.116 & 0.098 & 0.098 & 0.100 & NS & 0.154 & 0.148 & 0.156 & 0.144 & NS \\
\hline Palmitic & C16:0 & 18.368 & 18.248 & 18.546 & 18.430 & NS & 19.374 & 19.256 & 19.196 & 19.124 & $<.0001$ \\
\hline Heptadecanoic & C17:0 & 0.206 & 0.204 & 0.206 & 0.208 & NS & 0.256 & 0.276 & 0.256 & 0.256 & NS \\
\hline Stearic & C18:0 & 0.234 & 0.234 & 0.234 & 0.242 & NS & 0.296 & 0.296 & 0.322 & 0.298 & NS \\
\hline Nonadecylic & C19:0 & 0.050 & 0.052 & 0.050 & 0.050 & NS & 0.050 & 0.050 & 0.050 & 0.050 & NS \\
\hline Arachidic & C20:0 & 0.124 & 0.114 & 0.132 & 0.126 & NS & 0.164 & 0.178 & 0.188 & 0.196 & 0.00016 \\
\hline Behenic & $\mathrm{C} 22: 0$ & 0.048 & 0.048 & 0.050 & 0.050 & NS & 0.050 & 0.050 & 0.050 & 0.050 & NS \\
\hline Total & & 19.642 & 19.472 & 19.838 & 19.702 & & 21.176 & 20.93 & 20.902 & 20.744 & \\
\hline
\end{tabular}

$\mathrm{NS}=$ non-significant $(\mathrm{p}>0.05)$ 
Quadratic effect was observed for the Myristic acid, with the estimated level of $0.54 \%$ as the optimal point for the lowest presence of this acid. Palmitic acid showed decreasing linear effect with the inclusion of the mate in diets. Arachidic acid presented increasing linear effect with the inclusion of the mate in diets (Figure 2).
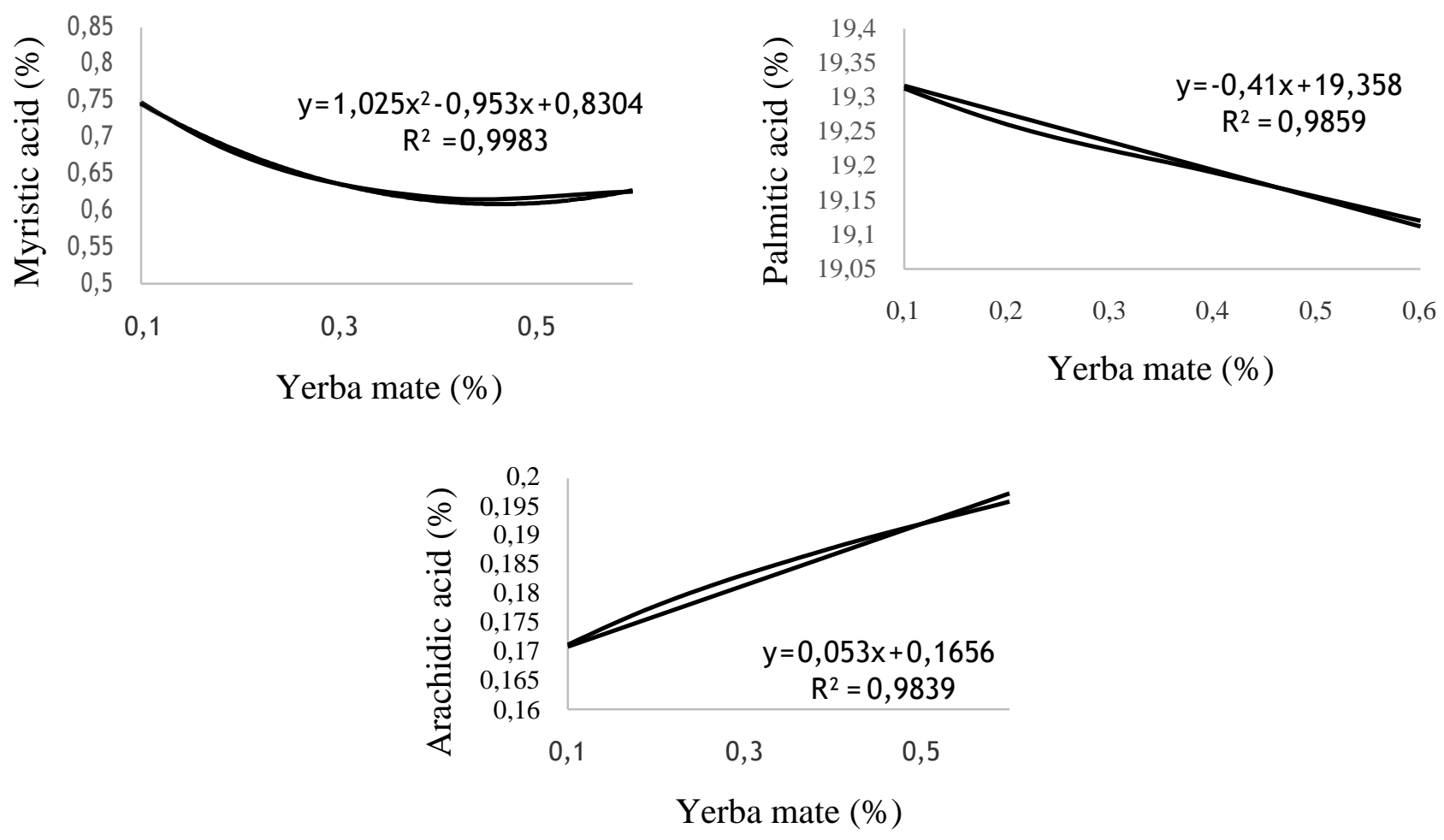

Figure 2. Effects of dietary Ilex paraguariensis (yerba mate) in broiler diet on saturated acids Myristic (a), Palmitic (b), and Arachidic (c) of thigh meat

Mono-unsaturated fatty (MUFA) acids profile was not affected by mate inclusion on diets for chicken breast meat (Table 3). 
Table3. Mono-unsaturated fatty acids (\%) in the broiler breast and thigh meat with different dietary level of Ilex paraguariensis (yerba mate).

\begin{tabular}{|c|c|c|c|c|c|c|c|c|c|c|c|}
\hline \multirow[b]{3}{*}{ FattyAcid } & & \multicolumn{4}{|c|}{ Breastmeat } & \multicolumn{6}{|c|}{ Thighmeat } \\
\hline & & \multicolumn{4}{|c|}{ Yerba mate $(\%)$} & \multicolumn{6}{|c|}{ Yerba mate $(\%)$} \\
\hline & & 0.1 & 0.2 & 0.4 & 0.6 & $\mathrm{p}$ & 0.1 & 0.2 & 0.4 & 0.6 & $\mathrm{p}$ \\
\hline Myristoleic & C14: 1 n5 & 0.106 & 0.110 & 0.106 & 0.100 & $\mathrm{NS}$ & 0.098 & 0.100 & 0.100 & 0.120 & NS \\
\hline Palmitoleic & C16:1 & 1.890 & 1.882 & 1.962 & 1.890 & $\mathrm{NS}$ & 1.782 & 1.746 & 1.738 & 1.862 & $<.0001$ \\
\hline Oleicacid & C18:1n9C & 27.824 & 27.832 & 27.844 & 27.862 & $\mathrm{NS}$ & 27.508 & 27.530 & 27.668 & 27.716 & $<.0001$ \\
\hline Cetoleic & $\mathrm{C} 20: \ln 11$ & 0.274 & 0.282 & 0.274 & 0.274 & NS & 0.254 & 0.248 & 0.254 & 0.248 & NS \\
\hline Ecozonoic & C20:1n9 & 0.022 & 0.020 & 0.020 & 0.022 & NS & 0.022 & 0.020 & 0.020 & 0.022 & NS \\
\hline Total & & 30.116 & 30.126 & 30.206 & 30.148 & & 29.664 & 29.644 & 29.78 & 29.968 & \\
\hline
\end{tabular}

NS= non-significant $(\mathrm{p}>0.05)$ 
Thigh meat MUFA presented effects in palmitocleic and oleic acids. Quadratic effect was observed for Palmitoleic with the estimated level of $0.24 \%$ as the minimum point for the lowest presence of this fatty acid. Oleic acid presented an increasing linear effect with the inclusion of mate in broilers diets (Figure 3).
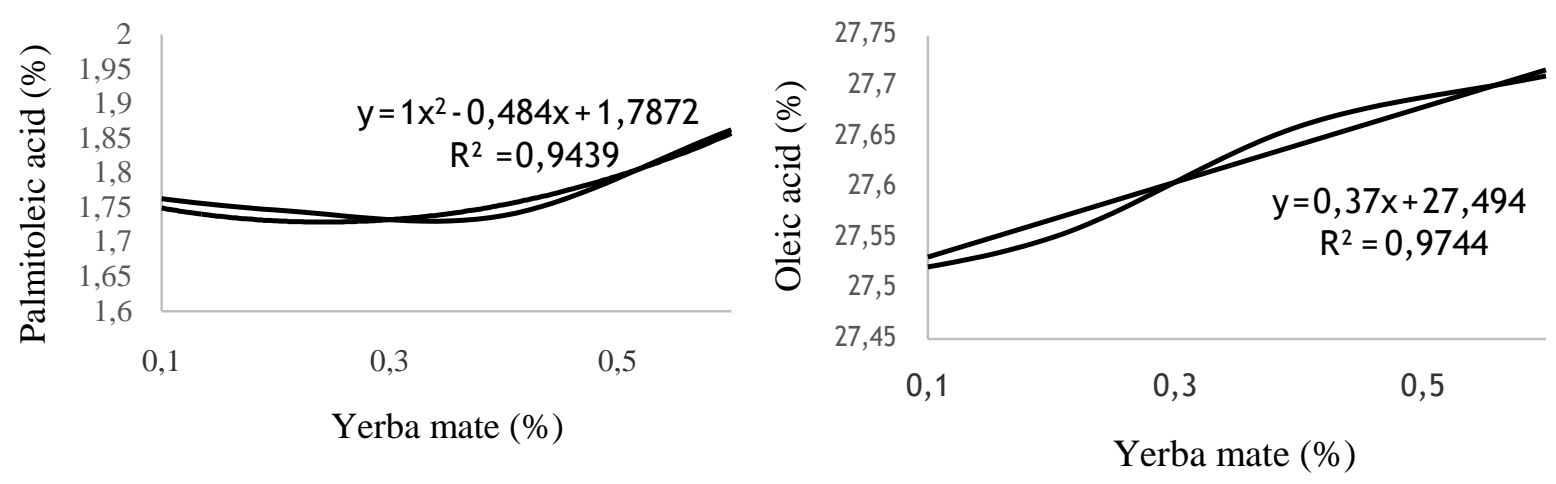

Figure 3. Effects ofdietaryIlex paraguariensis (yerba mate) on mono-unsaturated acids Palmitoleic (a), and Oleic (b) of thigh meat

The addition of mate in the diets demonstrated effect in the Poly-unsaturated fatty acids (PUFA) composition only in broilers thigh meat (Table 4). Quadratic effect was observed for eladic, linoleic and arachidonic acids, with the estimated levels of $0.16 \%, 0.19 \%$ and $0.22 \%$ as the minimum point for the lowest presence of these acids on broilers thigh meat, respectively (Figure 4). 
Table 4. Poly-unsaturated fatty acids (\%) in the broiler breast and thigh meat with different dietary level of Ilex paraguariensis(yerba mate).

\begin{tabular}{llcccccccccc}
\hline & & \multicolumn{4}{c}{ Breast meat } & \multicolumn{4}{c}{ Thigh meat } \\
\cline { 3 - 11 } Fat Acid & & \multicolumn{4}{c}{ Yerba mate $(\%)$} & \multicolumn{4}{c}{ Yerba mate $(\%)$} \\
Linoleic & $\mathrm{C} 18: 2 \mathrm{n} 6 \mathrm{c}$ & 31.938 & 32.014 & 32.152 & 32.216 & $\mathrm{NS}$ & 31.462 & 31.404 & 31.476 & 31.558 & $<.0001$ \\
Elaidic & $\mathrm{C} 18: 1 \mathrm{n} 9 \mathrm{t}$ & 9.986 & 10.044 & 10.090 & 10.200 & $\mathrm{NS}$ & 9.778 & 9.776 & 9.798 & 9.992 & $<.0001$ \\
ConjugatedLinoleic & $\mathrm{C} 18: 2 \mathrm{c} 9 \mathrm{t} 11$ (CLA) & 0.120 & 0.120 & 0.120 & 0.120 & $\mathrm{NS}$ & 0.120 & 0.114 & 0.120 & 0.120 & $\mathrm{NS}$ \\
a-Linolenic & $\mathrm{C} 18: 3 \mathrm{n} 3$ & 3.253 & 3.294 & 3.398 & 3.394 & $\mathrm{NS}$ & 3.111 & 3.132 & 3.300 & 3.292 & $<.0001$ \\
Arachidonic & $\mathrm{C} 20: 4 \mathrm{n} 6$ & 2.404 & 2.508 & 2.430 & 2.512 & $\mathrm{NS}$ & 2.340 & 2.294 & 2.348 & 2.392 & $<.0001$ \\
Eicosapentanoic & $\mathrm{C} 20: 5 \mathrm{n} 3$ & 0.124 & 0.128 & 0.128 & 0.134 & $\mathrm{NS}$ & 0.116 & 0.112 & 0.120 & 0.124 & 0.0039 \\
Total & & 47.825 & 48.108 & 48.318 & 48.576 & & 46.927 & 46.832 & 47.162 & 47.478 & \\
\hline
\end{tabular}

$\mathrm{NS}=$ non-significant $(\mathrm{p}>0.05)$ 
An increasing linear effect occurred with addition of mate in broilers diets in

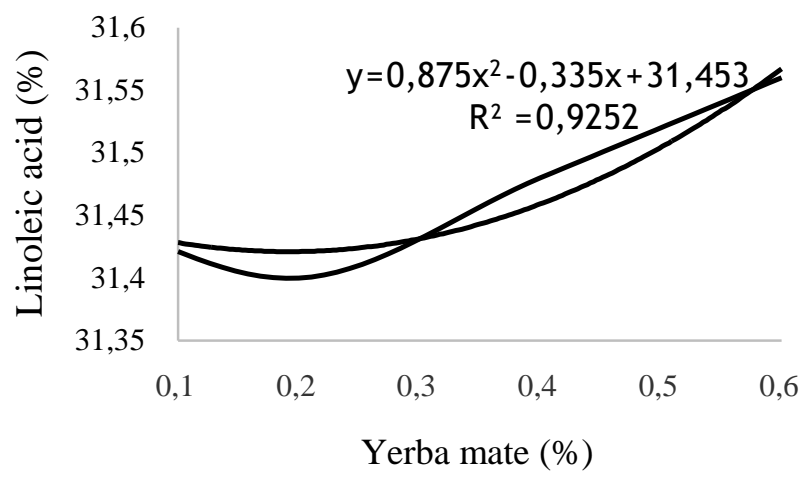

A

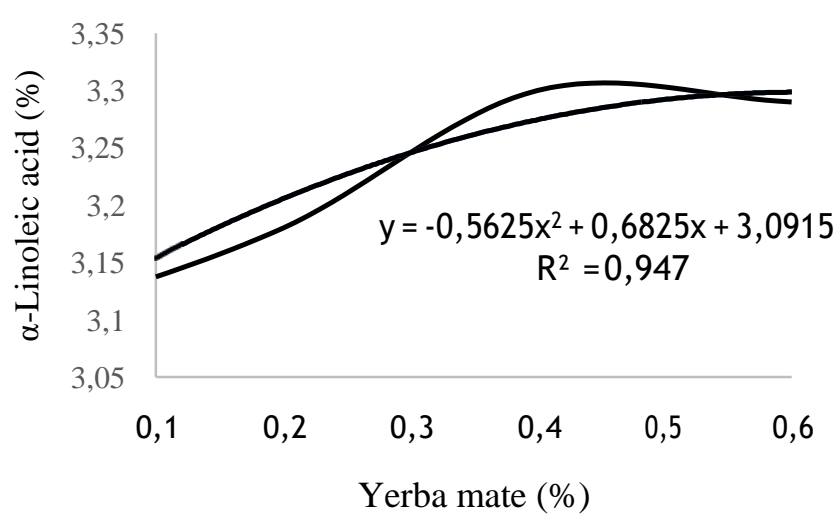

C

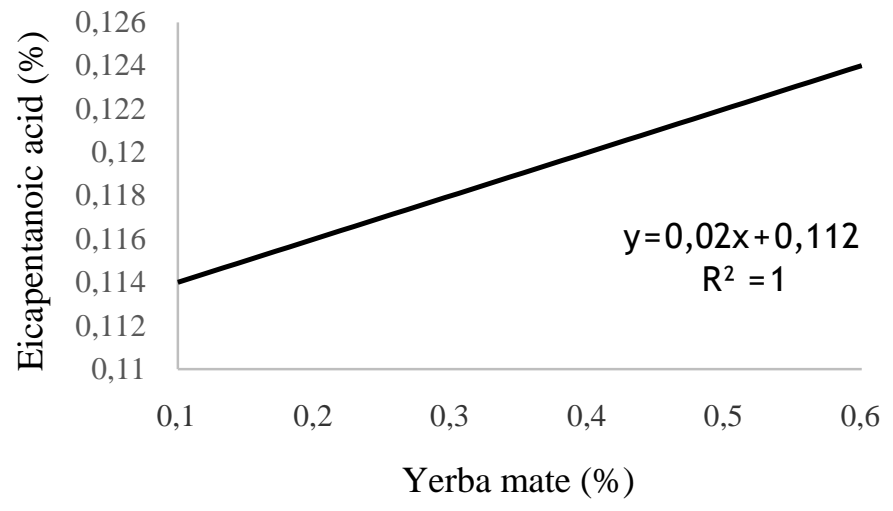

$E$

Figure 4.Effects of dietary Ilex paraguariensis (yerba mate) on poly-unsaturated acids Linoleic (a), Elaidic (b), $\alpha$-Linolenic (c), Arachidonic (d), and Eicozapentanoic (e) of thigh meat the $\alpha$-Linolenic and Eicosapentaenoic acids composition of thigh meat (Figure 4).

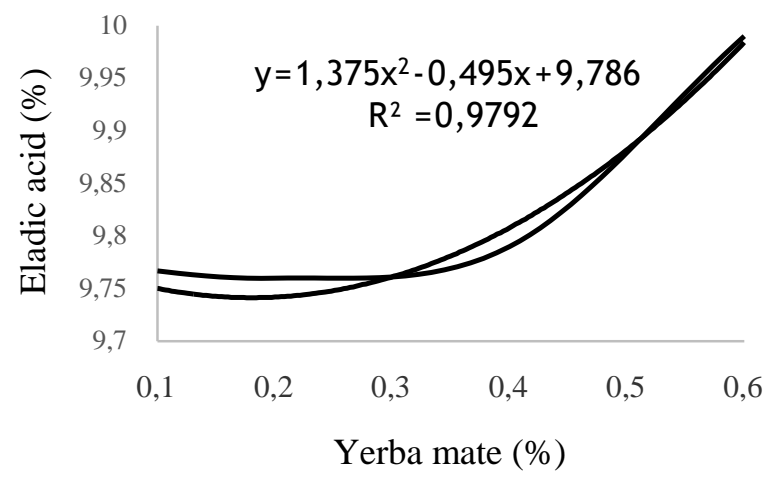

B

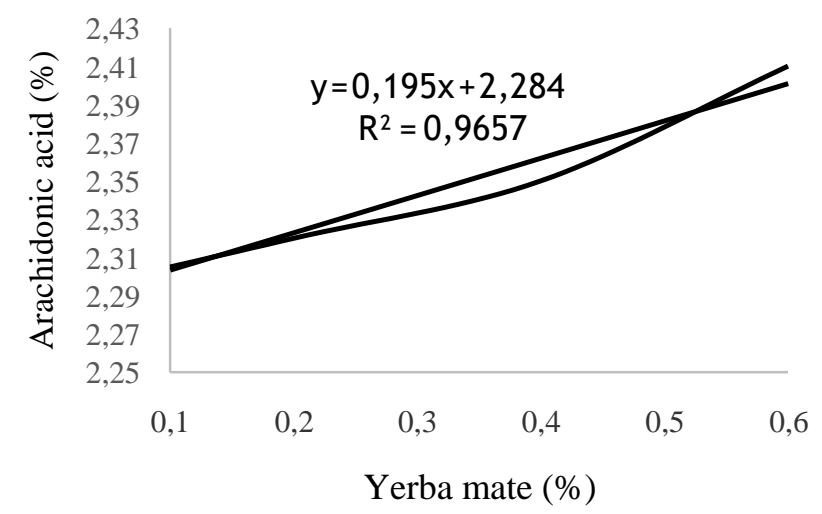

D 


\section{RESULTS AND DISCUSSION}

The chemical composition of Ilex paraguariensis includes several constituents that may be responsible for the numerous biological and pharmacological activities (Santos et al. 2015). The compounds found in high quantities are purine alkaloids (methylxanthines such as caffeine and theophylline), polyphenols (chlorogenic acids and its derivatives), saponins and flavonoids (Heck \& de Mejia, 2007).

Yerba mate is related with decreased deposition of fat in mice tissues (Arçari et al. 2009), as we could observe in our results, the inclusion of up to $0.35 \%$ of maté grass presented reduction in the ethereal extract in thighs muscle. This results are possibly related with saponins, which can interfere with cholesterol metabolism and delay the intestinal absorption of dietary fat via inhibition of pancreatic lipase activity (Han et al. 2002).

Meat lipids are mainly composed of triglycerides and phospholipids, which contain saturated fatty acids, monounsaturated fatty acids (MUFAs) and PUFAs (Jaturasitha et al. 2016).

Saturated fatty acids are not desirable in the meat due to the possibility of increasing serum levels of cholesterol and low-density lipoproteins, which may increase the development of cardiovascular diseases (Ahmed et al. 2015). Mate addition in broilers diets showed decreasing of Palmitic acid and a partial decrease of Myristic acid of thigh meat, improving its functional characteristics.

Myristic acid is the most worrying, since it increases the concentration of serum cholesterol 4 to 6 times more when compared to the presence of the Palmitic acid (Martin et al. 2006; McAffe et al. 2010). Contrary to the results observed for the Palmitic and Myristic acids, an increasing linear effect was observed for the Arachidic acid.

According to Heck et al. (2007), foliar ingredients usually present higher amounts of the Arachidic acid in its composition, as the case of grasses used as pasture. It is possible that Ilex paraguariensis has a significant presence of this lipid in its composition, which may explain the increase of this fatty acid in thigh meat of broilers fed with mate.

Kolouchová et al. (2015) reported that mono-unsaturated fatty acids reduce the alleged regulatory pool of intracellular free cholesterol, increasing LDL receptor activity and subsequently decreasing the blood circulating cholesterol concentrations.

Palmitoleic and oleic acids rich diets have been reportedas able to improve blood circulating lipid profile, resulting in reduced total and LDL cholesterol (Griel et al. 2008). Meat containing higher amounts of these fatty acids are desirable in human feed; animal feed enriched with safe and natural additives that promotes this improvement, as yerba mate, are an alternative to attend consumer's healthy demands.

Diets containing n-3 PUFA can improve animal fat (Wood et al. 2004), but is necessary associating this group of fatty acids with antioxidants to promote an enhancement of lipoperoxidation in plasma (Fuhrmann \& Sallmann, 1999; Scislowski et al. 2005). Natural antioxidants as yerba mate shows up as a safe alternative, rich in polyphenols, easily obtained from natural sources.

Accordingly, antioxidant effect of Ilex paraguariensis may have contributed to improving the deposition of poliunsaturated fatty acids from corn and soybean oil presents in the broiler diet. Ilexparaguariensis addition in broilers diets promoted an increasing of the $\alpha$ Linolenic and Eicosapentaenoic acids in 
broilers thigh meat. Fatty acid composition of meat can be modulatednutritionally in monogastric animals, thus Linoleic acid, $\alpha$-Linolenic acid, long-chain PUFA proportions respond quickly to elevated dietary concentrations (Jaturasitha et al. 2016). The interest in increasing levels of Eicosapentaenoic, Docosapentaenoic,Docosahexaenoic, and $\alpha$-linolenicis explained due to positive aspects of these $n-3$ fatty acids for the maintenance of long-term health and brain development in children (McAfee et al. 2010).

Functional foods aims to improve polyunsaturated fatty acids in its composition, those acids are essential to human health and can not be synthesized by the organism. Linolenic acid is a forerunner of $n-3$ and n-6 fatty acids by action of enzymes elongase and desaturase (Wood \& Enser, 2017), witch increased in thigh meat as another evidence of beneficial effect of addition of Ilex paraguariensis in broilers diets. Arachidonic acid also increased in thigh meat as an effect of yerba mate in broiler diets, which is a positive effect due to important role of action in immune system and in myelin sheath (Wood \& Enser, 2017) of this fatty acid. The inclusion of Ilex paraguariensis in broilers diet can be considered an alternative in the modulation of the fatty acid profile of broilers meat, especially for MUFA and PUFA.

\section{REFERENCES}

AHMED, S. T.; MANIRUL ISLAM, M. D.; RUBAYET BOSTAMI, A. B. M.; MUN, H-S.; KIM, Y-J.; YANG, C-J. Meat composition, fatty acid profile and oxidative stability of meat from broilers supplemented with pomegranate (Punicagranatum L.) by-products. Food Chemistry. Food Chemistry, v.188, p. 481488, 2015.
AOAC - Association of Official Analytical Chemists. Official Methods of Analysis. 20.ed. Gaithersburg: AOAC, 2016. v.1, $3172 \mathrm{p}$.

ARCARI, D.P.; BARTCHEWSKY, W.; SANTOS, T. W.; OLIVEIRA, K.A.; FUNCK, A.; PEDRAZZOLI, J.; SOUZA, M.F.F.; SAAD, M.J.; BASTOS, D.H.M.; GAMBERO, A, CARVALHO, P. O.; RIBEIRO, M.L. Antiobesity effects of yerba mate extract (Ilex Paraguariensis) in high-fat diet-induced obese mice. Obesity, v.17, n.12, p.2127-2133, 2009.

BLIGH, E. G.; DYER, W. J. A rapid method of total lipid extraction and purification. Canadian Journal of Biochemistry and Physiology, v.37, p. 911-917, 1959.

BRACESCO, N.; SANCHEZ, A. G.; CONTRERAS, V.; MININI, T.;

GUGLIUCCI, A. Recent advances on Ilex paraguariensis research: Mini review.

Journal of Ethnopharmacology, v.136, p.378- 384, 2010.

BRENNER RR. Nutritional and hormonal factors influencing desaturation of essential fatty acids. Progress in Lipid

Research,v.20, p. 41-7, 1981.

COBB-VANTRESS. Manual de Manejo de Frangos de Corte. Cobb-Vantress ed. p. 66. 2009.

FILIP, R.; LÓPEZ, P.; GIBERTI, G.; COUSSIO, J.; FERRARO, G. Phenolic compounds in seven South American Ilex species. Fitoterapia, v.72, p.774-778, 2001.

FUHRMANN H. AND SALLMANN H.P. (1999). Amount and type of unsaturated aldehydes in chicken plasma and tissues depend more on dietary lipids than on vitamin E status. Lipid. 34, 253-254. GRIEL, A. E.; CAO, Y. M.; BAGSHAW, D. D.; CIFELLI, A. M.; HOLUB, B. A Macadamia nut-rich diet reduces total and LDL-cholesterol in mildly hypercholesterolemic men and women. Journal of Nutrition, v. 138, p.761-767, 2008. 
HAN, L. K.; ZHENG, Y. N.; XU, B.; OKUDA, H.; KIMURA, Y. Saponins from platycodi radix ameliorate high fat dietinduced obesity in mice. Journal of Nutrition, v.132, p.2241-2245, 2002.

HECK C.I.; DE MEJIA, E.G. Yerba Mate Tea (Ilex paraguariensis): a comprehensive review on chemistry, health implications, and technological considerations. Journal of Food Science, v. 7, p. 138-151, 2007.

JATURASITHA, S.; CHAIWANG, N.; KAYANB, A.; KREUZER, M. Nutritional strategies to improve the lipid composition of meat, with emphasis on Thailand and Asia. Meat Science, v.120, p.157-166, 2016.

KOLOUCHOVÁ, I.; SIGLER, K.; SCHREIBEROVÁ, O.; MASÁK, J.; REZANKA, T. New yeast-based approaches in production of palmitoleic acid. Bioresource Technology, v.192, p.726-734, 2015.

KRAUSS, R. M.; ECKEL, R. H.; HOWARD, B; APPEL, L. J.; DANIELS, S. R.; DECKELBAUM, R. J. AHA dietary guidelines: Revision 2000: A statement for healthcare professionals from the Nutrition Committee of the American Heart Association. Circulation,v.102, p.22842299, 2000.

LANZETTI, M.; BEZERRA, F. S.; ROMANA-SOUZA, B.; BRANDO-LIMA, A. C.; KOATZ, V.L.; PORTO, L. C.; VALENCA, S. S. Mate tea reduced acute lung inflammation in mice exposed to cigarettes smoke. Nutrition, v. 24, p. 375381, 2008.

LEE, Ask the doctor. Is it true that drinking yerba mate can lower blood pressure and cholesterol? Harvard Health Letterv.18, p.8, 2007.

LIU, J.\& MA, D. W. L. The role of $n-3$ polyunsaturated fatty acids in the prevention and treatment of breast cancer. Nutrients, v.6, p.5184-5223, 2014.

MARMER, W. N.; MAXWELL, R. J. Dry column method for the quantitative extraction and simultaneous class separation of lipids from muscle tissue. Lipids, v. 16, p.365-371, 1981.

MARTIN, C. A.; ALMEIDA, V. V. D.; RUIZ, M. R.; VISENTAINER, J. E. L.; MATSHUSHITA, M.; SOUZA, N. E. D.; VISENTAINER, J. V. Ácidos graxos poliinsaturados ômega-3 e ômega-6: importância e ocorrência em alimentos. Revista de Nutrição, v. 19, p.761-770, 2006.

MCAFEE, A.; MCSORLEY, E.M.; CUSKELLY, G.J.; MOSS, B.W.; WALLACE, J. M. W.; BONHAM MP.; FEARON, A.M. Red meat consumption: An overview of the risk and benefit. Meat Science, v. 84, p.1-13, 2010.

\section{MINITAB 17. Statistical Software}

[Computer software]. State College, PA:

Minitab, Inc. (www.minitab.com). 2010.

MOLEE, W., PUTTARAKSA, P., \& KHEMPAKA, S. Effect of rearing systems on fatty acid composition and cholesterol content of Thai indigenous chicken meat. World Academy of Science, Engineering and Technology, v.6, p.628-630, 2012.

MOSIMANN, A. L. P.; WILHELMFILHO, D.;DA SILVA, E. L. Aqueous extract of Ilex paraguariensis attenuates the progression of atherosclerosis in cholesterol-fed rabbits. Biofactors, v. 26, p.59-70, 2006.

RACANICCI, A.M.C.; DANIELSEN, B.; SKIBSTED, L.H. Mate (Ilex paraguariensis) as a source of water extractable antioxidant for use in chicken meat. European Food Research and Technologyv. 227, p. 255-260, 2008.

ROSTAGNO, H. S.; ALBINO, L. F. T.; DONZELE, J.L.; GOMES, P.C.; OLIVEIRA, R.F.; LOPES, D.C.; FERREIRA, A.S.; BARRETO, L.S.T.; EUCLIDES, R. F. Brazilian tables for broilers and swine: Composition for feed and nutritional demands (Portuguese). 3rd ed. University of Viçosa Press. Viçosa, Brazil, 2011. 
SANTOS, E.C.S,; BICCA, M.A.; BLUM-

SILVA, C.H.; COSTA, A.P.R.; DOS

SANTOS, A.A.; SCHENKEL, E. P.;

FARINA, M.; REGINATTO, F. H.; LIMA,

T. C.M. Anxiolytic-like, stimulant and neuroprotective effects of Ilex

paraguariensis extracts in mice.

Neuroscience, v.292, p.13-21. 2015.

SCISLOWSKI V.; BAUCHART D.;

GRUFFAT D;, LAPLAUD P.M.;

DURAND D. Effect of dietary n-6 or n-3

polyunsaturated fatty acids protected or not

against ruminal hydrogenation on plas-ma

lipids and their susceptibility to

peroxidation in fattening steers. Journal

Animal Sciencev.83, p. 2162-2174, 2005.

WOOD, J.D.; RICHARDSON R.I.; NUTE G.R.; FISHER A.V.; CAMPO M.M.;

KASAPIDOU E.; SHEARD P.R.; ENSER

M.Ef-fects of fatty acids on meat quality: a review. Meat Science,v.66, p. 21-32, 2004.

WOOD, J. D.\& ENSER, M. Manipulating the Fatty Acid Composition of Meat to

Improve Nutritional Value and Meat

Quality. New Aspects of Meat

Qualityp.501-535, 2017.

WOOD, J.D.; LAMBE, N.R.; WALLING,

G.A.; WHITNEY, H.; JAGGER, S.;

FULLARTON, P.J.; BAYNTUN, J.;

HALLETT, K.; BUNGER, L. Effects of

low protein diets on pigs with a lean

genotype. 1. Carcass composition measured

by dissection and muscle fatty acid

composition. Meat Science, v.95, p.123-

128, 2013. 